\title{
Genealogi Tradisi Shalawat Nariyah di Desa Kroya Cilacap
}

\section{Achmad Fachrur Rozi*}

\section{UIN Sunan Kalijaga Yogyakarta}

Jl. Laksda Adisucipto, Kabupaten Sleman, Daerah Istimewa Yogyakarta 55281

\begin{tabular}{l|l|l} 
Submitted: $16^{\text {th }}$ Jan 2020 & Revised: 22th Jan 2020 & Accepted: $2^{\text {nd }}$ Mar 2020
\end{tabular}

Abstract This article discusses the living of hadith, namely the study of the phenomena of practice or ritual originating from hadith. The tradition of Shalawat Nariyah which is one of the popular prayers that has taken root in Indonesian society. In Kroya Village, the Shalawat Nariyah Tradition is held every Wednesday night with 4444 congregations. The congregation is spread throughout the Kroya village mosque and takes turns every week. They believe that reading Shalawat Nariyah is able to facilitate sustenance. As generally the Shalawat Nariyah Tradition in some places is held on Friday nights, this is in line with the recommendations of the Prophet's hadith. But in Kroya, the tradition of reciting Shalawat Nariyah is held every Wednesday night.

Keywords: Living Hadith, Tradition of Shalawat Nariyah, Genealogi, Kroya.

Abstrak Artikel ini membahas mengenai living hadis, yakni kajian terhadap fenomena praktik ataupun ritual yang bersumber dari hadis. Tradisi Shalawat Nariyah yang merupakan salah satu shalawat populer yang sudah mengakar di kalangan masyarakat Indonesia. Di Desa Kroya, Tradisi Shalawat Nariyah ini dilaksanakan setiap malam Rabu dengan berjamaah sebanyak 4444 kali. Jamaahnya tersebar di seluruh masjid Desa Kroya dan bergiliran tiap minggunya. Mereka percaya bahwa membaca Shalawat Nariyah mampu memperlancar rezeki. Sebagaimana umumnya Tradisi Shalawat Nariyah di beberapa tempat dilaksanakan di malam Jumat, hal ini sejalan dengan anjuran hadis nabi. Namun di Kroya, tradisi pembacaan Shalawat Nariyah ini digelar setiap malam Rabu.

Kata Kunci: Living Hadis, Tradisi Shalawat Nariyah, Genealogi, Kroya. 


\section{PENDAHULUAN}

Pembacaan terhadap hadis melalui pendekatan kebahasaan dan kesusastraan melahirkan pemahaman hadis secara tekstual. Penerimaan hadis sebagai teks rentan mengurangi nilai-nilai aktualnya sebagai diskursus yang hidup dalam kehidupan sehari-hari. Kebutuhan untuk menjadikan hadis bernilai dalam kehidupan sehari-hari kaum muslimin, di salah satu sisi memaksa mereka memahami hadis dalam batas konteks dan kemampuan masing-masing, di sisi lain juga mempengaruhi bentuk ujaran dari hadis untuk membangun diskursus yang hidup dengan penerimanya (Rafiq, 2005: 204; Hidayah, 2018).

Di dalam pembahasan tentang agama, kajian living hadis adalah bagian dari pembahasan lived Religion, practical religion, popular religion, lived Islam, yang bertujuan untuk mengetahui sejauh mana manusia dan masyarakat memahami, memaknai dan menjalankan ajaran agama mereka, untuk tidak lagi mengutamakan kaum-kaum elit saja dalam agama (pemikir, otoritas agama, pengkhotbah, dan sebagainya). Living Hadis ialah hadis yang bisa digunakan yang bermula dari ijtihad yang disepakati dalam suatu kelompok muslim yang di dalamnya terdapat ijma' dan kesepakatan para ulama' dan tokoh-tokoh agama di dalam kegiatannya (Mustaqim dan Syamsuddin, 2007). Kajian living hadis dapat melihat bagaimana hadis ini bisa hidup dan bahkan gencar disuarakan oleh komunitas Islam tertentu, sehingga living hadis tidak hanya melihat fenomena atau kebiasaan masyarakat yang ternyata memiliki sumber hadis yang populer, tetapi juga melihat bagaimana hadis-hadis tertentu yang sudah dianggap sahih bisa hidup dan menjamur dengan pemahaman yang terkesan tekstual dan radikal. (Assegaf, 2015: 309; Fikri, 2018).

Living hadis memiliki tiga model yang pertama tradisi tulisan, tradisi lisan dan tradisi praktik (Anwar, 2015: 74). Tradisi menulis sangatlah penting di dalam perkembangan living hadis. menulis tidak hanya sebagai bentuk ungkapan yang sering terpajang di tempat-tempat yang strategis atau tempat yang ramai. Ada juga tradisi yang kuat di dalam lingkungan Indonesia yang bersumber dari hadis Nabi Muhammad yang terpajang dalam berbagai tempat yang strategis dan juga terpajang dalam beberapa acara atau tempat-tempat umum. Tidak semua yang terpampang berasal dari hadis Nabi Muhammad salah satu di antaranya adalah yang bukan hadis melainkan sebuah slogan atau kata mutiara tetapi masyarakat menganggapnya sebagai hadis. Salah satu contohnya adalah tentang kebersihan itu sebagian dari iman slogan ini bertujuan untuk menghadirkan suasana nyaman dan kebersihan lingkungan. Membahas dan menelaah hadis tidak dapat diartikan atau pahami secara 
tekstual saja. Maka harus membaca dan memahami yang melatar belakangi adanya hadis tersebut. Hadis tersebut tidak dapat atau tidak berlaku umum misalnya ada peristiwa khusus yaitu tanggapan Nabi Muhammad.

Salah satu contoh model living hadis lisan (oral) adalah shalawat. Shalawat berasal dari bahasa Arab yaitu shalat jamaknya shalawat, yang arti dasarnya ialah mendoakan atau berdoa. Membaca shalawat dalam arti keagamaan umat Islam adalah mendoakan Nabi Muhammad untuk mendapatkan rahmat dari Allah dan perintah bershalawat untuk Nabi Muhammad ini merupakan, perintah langsung dari Allah kepada hambaNya. Dalam rangka mengamalkan perintah agama tersebut, ada banyak cara yang dilakukan dengan berbagai macam tujuan dan maksud, baik yang bersifat keagamaan atau kemasyarakatan. Beberapa contoh shalawat dilakukan pada saat ada acara pengajian atau yasinan di kalangan masyarakat. Seperti menumbuhkan silaturahmi antar masyarakat dan tradisi ini sudah berangsur-angsur ada sejak lama atau sejak zaman dahulu.

Ada beberapa macam shalawat yang dikenal dalam masyarakat, seperti: Shalawat Nariyah, Shalawat Munziat, Shalawat Tibil Qulub, Shalawat Shifa, Badawiyah, Qubra, Kamaliyah, Ibrahimiyah, Basyairul khairat, Bariyyah, Nurizati, Asnawiyah, Nurul Anwar, dan masih banyak lainnya. Dari beberapa shalawat tersebut mempunyai arti dan kegunaan masing masing. Shalawat Nariyah, lebih dikenal dengan istilah shalawat kamilah atau biasa disebut Shalawat Tafrijiyah, shalawat ini memiliki beberapa keutamaan atau kegunaan di antaranya adalah menghilangkan kecemasan, menghilangkan kesulitan dan penyakit, membukakan kelapangan atau segala kebaikan, meninggikan kedudukan, meluaskan rizki dan masih banyak lainnya.

Jika berbicara mengenai perkembangan tradisi shalawat di Indonesia dipengaruhi oleh beberapa faktor, di antaranya, pertama, secara normatif, cukup banyak hadis Nabi yang membahas mengenai fadhilah shalawat. Cukup banyak hadis Nabi yang secara khusus membahas mengenai shalawat, salah satunya yaitu shalawat tersebut dapat mengabulkan suatu hajat. Hal ini berdasarkan hadis Nabi, yaitu:

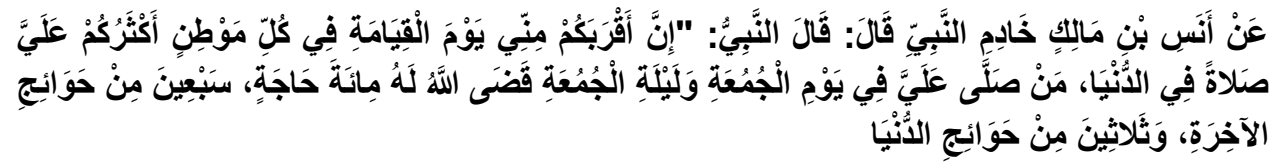

“Dari Anas ibn Malik, Rasulullah SAW bersabda: "barang siapa yang bershalawat kepadaku pada hari jumat dan malam jumat sebanyak 100 


\section{Achmad Fachrur Rozi}

kali, maka Allah akan mengabulkan 100 hajat darinya, 70 hajat akhirat dan 30 hajat duniawi." Kedua, konstruksi tokoh-tokoh agama dalam membentuk tradisi. Tulisan ini akan fokus terhadap genealogi tradisi Shalawat Nariyah, khususnya di Desa Kroya.

\section{HASIL DAN PEMBAHASAN}

Desa Kroya merupakan desa yang paling multikultural di Kecamatan Kroya, terbukti dengan beragamnya agama yang dianut oleh masyarakat setempat, antara lain Islam, Katholik, Protestan dan Buddha. Meskipun demikian, pemeluk agama Islam di Desa Kroya tercatat sebesar 96,09\%, menyusul berikutnya Katholik sebesar 2,63\%, Protestan sebesar 1,05\% dan Buddha sebesar 0,23\% dari total penduduk sebesar 8185 jiwa. Diagram Jumlah Pemeluk Agama Desa Kroya. Selain itu sarana dan prasarana pendukung peribadatan juga memadai, yakni dengan adanya Masjid maupun Mushala dengan jumlah 38 bangunan dan Gereja sebanyak 2 bangunan.

\section{Genealogi Tradisi Pembacaan Shalawat Nariyah di Desa Kroya}

Fenomena shalawat memiliki historisitas panjang menjadi tradisi rutin shalawat nariyah yang dilakukan secara berjamaah merupakan visualisasi hadis. Nurcholish Madjid percaya bahwa tatanan umat yang ideal harus dibangun berdasarkan prinsip-prinsip jamaah, dengan mengedepankan keterbukaan dan inklusivisme, serta bersedia untuk mengakui pluralisme dan membuka diri untuk dialog. Pengertian jamaah juga mencakup semangat nonsektarian (Madjid, 1989: 61-80). Masyarakat percaya bahwa shalawat merupakan perwujudan penghormatan masyarakat terhadap sosok Nabi Muhammad sebagai Nabi dan Rasul terlihat dari tradisi ini yang rutin dilaksanakan secara berjamaah setiap pekan.

Pada awal terciptanya, Shalawat Nariyah disebut Shalawat Tafrijiyah. Namun, nampaknya sejarawan mempunyai datayang berlainan. Adapula yang menamainya Shalawat Kamilah yang dikutip dari redaksi shalawat tersebut. Karena di teks yang berbeda, ditemukan bahwa shalawat ini dahulu bernama Naziyah, yang bermula dari penisbatan muasal teks shalawat ini kepada Syaikh Ibrahim an-Nazi. Kemudian sebutan Naziyah ini bertransformasi menjadi Nariyah hanya sebatas tahrif, memutar kata dengan perubahan pada titiknya. Ada pula yang berpendapat bahwa Nariyah muncul sebagai sesuatu yang lebih historis. Kalangan Islam Maroko, ketika ingin mendapatkan yang dikehendaki sekaligus menghindari yang dibenci, mereka segera berkumpul dalam satu majelis. Di dalamnya, mereka membaca shalawat 
ini sebanyak 4.444 kali, maka yang diharapkan akan terwujud segera, secepat kobaran api (an-nâr) ketika membakar jerami (An-Nazy: 179).

Dari kata an-nâr inilah nama Nariyah bermula. Para sufi menyebutnya Miftah al-Kanz al-Muhid linaili Murad al-'Abid (shalawat kunci yang dapat membuka pintu gudang harta karun). Versi lain menyebutkan bahwa penyusun shalawat nariyah yaitu Imam Abu Abdillah Ibn Ahmad Ibn Abi Bakr al-Anshari al-Andalusi al-Qurtubi, seorang pakar ilmu tafsir populer yakni kitab Tafsir Al-Jami' li Ahkam alQur'an (Husni, 2012: 34).

Tradisi Shalawat Nariyah di Desa Kroya sudah berjalan turuntemurun dari generasi ke generasi. Tradisi shalawat di Desa Kroya dimotori oleh sesepuh Kyai setempat atau tokoh yang cukup berpengaruh di masyarakat. Hal ini dalam rangka mengubah kondisi masyarakat menuju tatanan yang lebih baik secara moral, ekonomi, dan politik (Iskandar, 2007: 31).

Menurut Kyai Waridin, Tradisi Shalawat Nariyah ini pertama kali digelar di Masjid (Haedari, 2004: 33-34) Miftahul Huda, komplek Pondok Pesantren Miftahul Huda Kroya. dipelopori oleh Kyai Haji Nur Hasyim pada tahun 1977. Dari penelusuran penulis ia merupakan ketua takmir Masjid Miftahul Huda kala itu. Kemunculan tradisi di masjid lingkungan pesantren ini bukan hal yang tabu, karena salah satu peran masjid yakni merupakan pusat kebudayaan. Jaringan-jaringan pengajian agama di lingkungan masyarakat luas dibangun, kitab-kitab keagamaan ditulis dan disebarluaskan, dan tradisi-tradisi muncul dan berkembang hingga akhirnya mampu bertahan hingga saat ini dari generasi ke generasi.

Peran pondok pesantren di sini juga terbilang vital, karena Kyai Haji Nur Hasyim sendiri termasuk santri jebolan pesantren tersebut. Tradisi ini merupakan transmisi dari keprihatinan Kyai Haji M Minhajul Adzkiya yang merupakan ayah dari $\mathrm{KH}$ Su'ada, melihat kondisi masyarakat di sekitar Kroya yang masih kekurangan sentuhan nilai-nilai Islami. Karena itu pada tahun 1951/1962, Kiai Minhajul Adzkiya bersama KH Munawwir Alhafidz mendirikan Pondok Pesantren Miftahul Huda Kroya, sebagai media untuk berdakwah dan mengkader santri, agar dapat mensyiarkan agama Islam. Embrio pondok pesantren ini sebenarnya sudah ada sejak sebelum kemerdekaan, namun secara resmi baru didirikan pada tahun 1951.

Kyai satu dengan yang lainnya selalu terjalin oleh Intellectual Chain (rantai intelektual) yang tidak terputus. Ini berarti bahwa antara satu pesantren dengan pesantren yang lain dalam satu kurun zaman maupun dari satu generasi berikutnya, terjalin hubungan intelektual yang mapan, sehingga perkembangan dan perubahan yang terjadi dalam lingkungan 


\section{Achmad Fachrur Rozi}

pesantren sebenarnya sekaligus dapat menggambarkan sejarah intelektual Islam tradisional. Dengan demikian, dalam tradisi pesantren, seorang Kyai tidak akan memiliki status dan kemasyhuran hanya karena kepribadian yang dimilikinya. Ia menjadi Kyai karena ada yang mengajarnya. Ia pada dasarnya mewakili watak pesantren dan gurunya. Keabsahan ilmunya dan jaminan yang ia miliki sebagai seorang yang diakui sebagai murid Kyai terkenal dapat ia buktikan melalui mata rantai transmisi yang biasanya ia tulis dengan raih dan dapat dibenarkan oleh Kyai-kyai lain yang masyhur yang seangkatan dengan dirinya (Azra, 1994: 268-270). Rantai transmisi seperti ini dalam pesantren disebut sanad.

Kyai memiliki kemampuan melakukan perubahan sosial dengan caranya sendiri, sebetulnya lebih disebabkan faktor keberadaan pesantren yang umumnya berada di pedesaan. Sehingga di satu sisi membawa faktor-faktor perubahan, namun di sisi lain mesti menjaga keseimbangan dengan alam dan kehidupan desa (Horikoshi, 1987: 223). Bahkan menurut Kuntowijoyo, menyebut Kyai di pedesaan selain identik dengan pendiri pesantren, juga sebagai pelopor pembangunan masyarakat desa (Kuntowijoyo, 1991: 321).

Pesantren memainkan peranan kunci dalam penyebaran Islam dan pemantapan ketaatan masyarakat kepada Islam di Jawa. Melalui pesantren dapat dibentuk watak keislaman kerajaan-kerajaan Islam, dan yang memegang peranan paling penting bagi penyebaran Islam sampai ke pelosok-pelosok (Mas'ud, 1997: 40).

Saat terjadi aksi militer Belanda II (Clash II), beliau bersama beberapa warga dan santri mengungsi ke Ngasinan, di Kebasen Banyumas, sebelum akhirnya pindah lagi ke Rawaseser (sebuah Dusun di Desa Mujur, Kecamatan Kroya). Dalam keadaan tidak menentu, beliau tetap istiqamah dalam proses belajar mengajar. Pasca Clash II dan suasana sudah aman, Kyai kembali ke Kroya. Tetapi ternyata tempat tinggalnya, berikut asrama dan mushala sudah rata dengan tanah. KHM Adzkiya merupakan sosok yang tegar, tidak mudah patah semangat.

Ketika mengetahui tempat tinggal dan asrama santri sudah rata dengan tanah, beliau pindah ke Kauman Kroya. Di sini, Kiai sekaligus memimpin Kantor Urusan Agama (KUA) Kecamatan Kroya. Kyai Adzkiya sempat memberikan pengajian kepada orang-orang di sekitar Kauman, sampai akhirnya diangkat untuk memimpin Pengadilan Agama di Kabupaten Wonosobo. Tugas negara itu mengharuskannya pindah ke Wonosobo sampai pensiun 1962. 
Kyai Haji Muhammad Adzkiya merupakan salah satu pendiri Nahdlatul Ulama (NU) di kabupaten Cilacap, yang secara resmi didirikan di Kroya pada 1936. Beliau begitu tegas dan berani. Setiap ada serangan yang dilakukan oleh Islam garis keras kepada NU, atau dari pihak lain, dia tidak segan mengajak berdebat siapa saja, guna meluruskan kesalahpahaman yang sering dilontarkan kepada NU. Maksud dari beliau adalah baik, yaitu jangan sampai Islam yang rahmatan lil 'alamin, dinodai oleh klaim-klaim sebagian golongan Islam, sebagai yang paling benar. Prinsip ini dibawa sampai dengan akhir hayatnya, pada 1981.

Nahdlatul Ulama sebagai komunitas muslim yang umumnya terbentuk dalam proses sejarah Islam Indonesia yang mula-mula dekonsentrasi di pedesaan dengan mata pencaharian mayoritas bertani (Ali dan Effendi, 1986: 233). Di samping itu, mereka lekat dengan budaya lokal, tanah Jawa yang subur, sebagai budaya di mana orang-orang NU dan kelahiran NU sendiri berasal dari pulau Jawa. Akar sejarah yang demikian ini melahirkan pemotretan sosial adanya kerapatan, bahkan tak terpisahkan antara budaya Jawa dengan eksistensi kaum Nahdliyin (Qomar, 2000: 11-30). Sikap kaum Nahdliyin yang mampu menyesuaikan antara agama dan budaya Jawa khususnya dan umumnya budaya Indonesia, melalui proses rekonsiliasi dan akomodasi. Akibatnya, kaum Nahdliyin mampu akrab dengan budaya setempat dan mempunyai tradisi yang kuat dalam menjalankan syariat Islam. Cara yang ditempuh NU dalam menghadapi budaya setempat adalah tidak bersikap menghancurkan, namun sedapat mungkin membiarkan hidup di masyarakat sambil mengisinya dengan jiwa dan semangat Islam. Hal ini menjadi salah satu sumber kekuatan NU, sehingga lahirnya NU tidak berhadapan dengan budaya di masyarakat, bahkan mampu menyatukan aspirasi kebudayaan dengan aspirasi keislaman (Ismail, 1998: 56-72). Selanjutnya, kebudayaan itu dikembangkan sebagai bagian dari kehidupannya.

Kemampuan NU mendudukkan kebudayaan secara proporsional seharusnya menempatkan NU sebagai organisasi yang memelihara tradisi Islam di Indonesia (Wahid, 2001: 83). Kekuatan ini bukan hanya terletak pada pola pikir tradisionalnya, melainkan karena NU memiliki prinsip sebagai khadim al-ummah atau pelayan umat. Implikasi ini memungkinkan NU populis di tengah-tengah masyarakat tanpa mengalami konfrontasi dengan mereka. Karena kerapatan dan tidak dapat terpisahkannya dengan kebudayaan setempat, telah memosisikan eksistensi NU didukung oleh berbagai kelompok sosial maupun aliran seperti oleh kaum abangan. Tradisi yang dihayatinya selalu menjadi 


\section{Achmad Fachrur Rozi}

modal utama dalam menentukan pilihan yang tepat di masa kini dan mendatang (Wahid, 2001: 52). Pembacaan shalawat merupakan salah satu bentuk ekspresi ritualitas dan seni yang menggabungkan unsur kreatif, estetika dan ritus yang hidup dan dipelihara di lingkungan Nahdliyin. Kyai dan santri berusaha untuk melestarikan budaya tersebut. Adapun hadis-hadis yang menjadi landasan tradisi shalawat ini adalah, hadis tentang perintah bershalawat. Membaca selawat atau bershalawat kepada Nabi berarti mendoakan atau memohonkan berkah kepada Allah swt untuk Nabi. Ada beberapa hadis yang menjadi landasan terbentuknya rutinitas kegiatan tersebut, yakni: Hadis dari Abu Hurairah r.a, ia berkata bahwa Rasulullah shallallahu 'alaihi wa sallam bersabda:

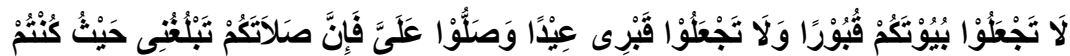

“Janganlah jadikan rumahmu seperti kubur, janganlah jadikan kubur sebagai 'ied, sampaikanlah shalawat kepadaku karena shalawat kalian akan sampai padaku di mana saja kalian berada."

Selain itu, landasan yang dijadikan kegiatan ini bersemangat diadakan setiap minggu adalah beberapa hadis berikut; Hadis dari Abu Hurairah bahwa Rasulullah saw. bersabda:

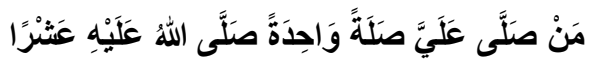

Siapa yang mengucapkan shalawat kepadaku satu kali, maka Allah mengucapkan shalawat kepadanya 10 kali.

Salah satu hadis yang memotivasi seseorang membaca shalawat ialah hadis dari Anas bin Malik ra., bahwa Rasulullah saw. bersabda:

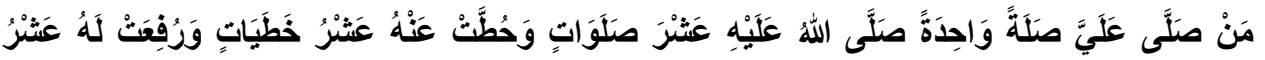

Siapa membaca shalawat untukku, Allah akan membalasnya 10 kebaikan, diampuni 10 dosanya, dan akan ditambah 10 derajat baginya. Maka tidak heran jika Nahdliyin, setiap kegiatannya selalu disisipi dengan shalawat dengan beraneka ragamnya, salah satunya Shalawat Nariyah. 
Adapun dasar dalil tentang shalawat Nariyah yang digunakan, antara lain:

Dasar yang digunakan, pertama:

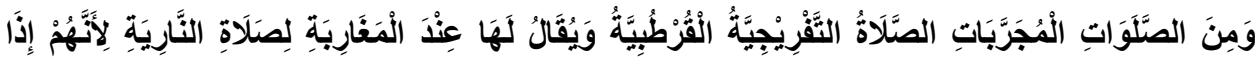

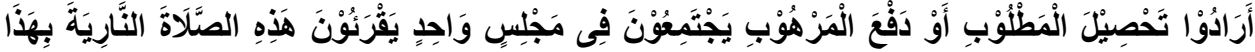

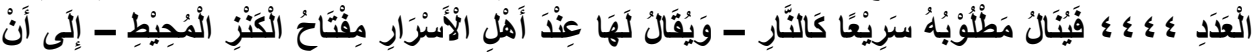

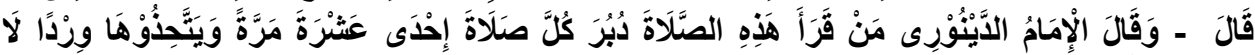

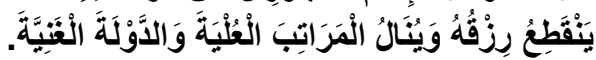

Salah satu shalawat yang mustajab ialah shalawat Tafrijiyah Qurthubiyah yang disebut orang Maroko shalawat Nariyah karena jika mereka (umat Islam) mengharapkan apa yang dicita-citakan, atau ingin menolak yang tidak disukai, maka mereka akan berkumpul dalam satu majelis untuk membaca shalawat Nariyah ini sebanyak 4444 kali maka tercapailah apa yang dikehendaki dengan cepat (bi idznillah). Shalawat ini juga oleh "orang-orang yang tahu rahasia ilahi" diyakini sebagai "kunci gudang yang memadai". Sampai kata-kata... Imam Dainuri memberikan komentarnya: Siapa yang membaca shalawat ini sehabis salat (fardhu) 11 kali digunakan sebagai wiridan maka rezekinya tidak akan putus, di samping mendapatkan pangkat/kedudukan dan tingkatan orang yang kaya (An-Nazy, 1993: 202-203).

Dalil kedua:

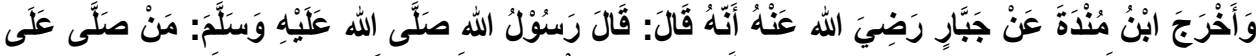

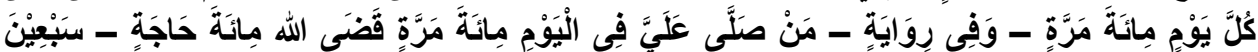

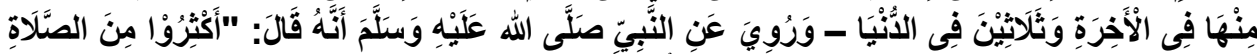

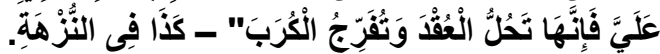

Hadis riwayat Ibnu Mundah dari Jabir, ia mengatakan: Rasulullah bersabda: Siapa yang membaca shalawat kepadaku sehari 100 kali (dalam riwayat lain): Siapa yang membaca shalawat kepadaku 100 kali Allah akan mengabulkan 100 kali hajatnya: 70 hajatnya di akhirat, dan 30 di dunia. Sampai kata-kata... Juga, hadis Rasulullah yang mengatakan: Perbanyaklah shalawat kepadaku karena dapat memecahkan masalah dan menghilangkan kesedihan. Demikian seperti tertuang dalam kitab alNuzhah (An-Nazy, 1993: 201). 
Dalil ketiga:

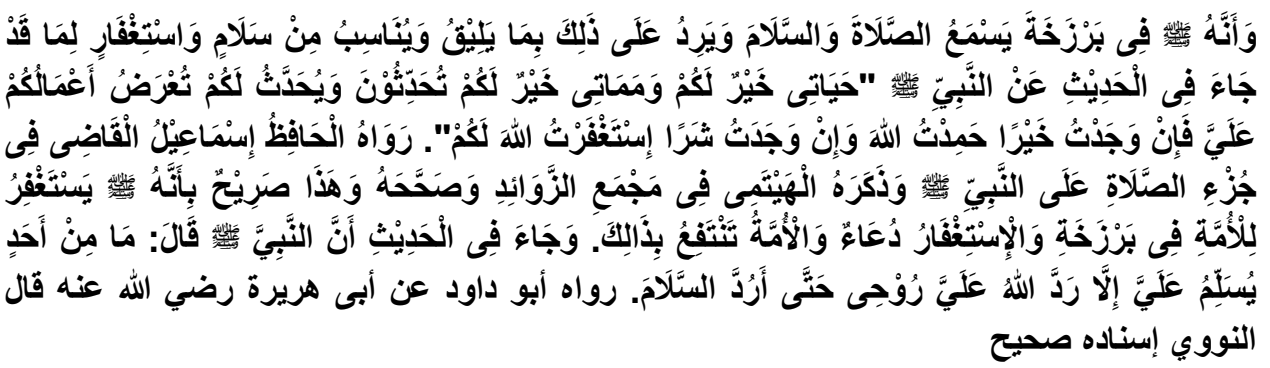

Rasul di alam barzakh mendengar bacaan shalawat dan salam dan dia akan menjawabnya sesuai jawaban yang terkait dari salam dan shalawat tadi. Seperti tersebut dalam hadis, dia bersabda: Hidupku, juga matiku, lebih baik dari kalian. Kalian membicarakan dan dibicarakan, amal-amal kalian disampaikan kepadaku; jika saya tahu amal itu baik, aku memuji Allah, tetapi kalau buruk aku mintakan ampun kepada-Nya. Hadis riwayat al-Hafidz Ismail al-Qadhi, dalam Bab Shalawat 'ala anNaby. Imam Haitami menyebutkan dalam kitab Majma' az-Zawaid, ia menilai shahih hadis di atas. Hal ini jelas bahwa Rasulullah memintakan ampun umatnya meski di alam barzakh sana. Istighfar adalah doa, dan doa untuk umatnya pasti berguna. Ada lagi hadis lain, Rasul bersabda: Tidak seorang pun yang memberi salam kepadaku kecuali Allah akan menyampaikan salam itu kepada ruhku sehingga aku bias menjawabnya (HR. Abu Dawud dari Abu Hurairah. Ada di kitab Imam an-Nawawi, dan sanadnya shahih)(Al-Maliky: 56-57).

Tradisi Pembacaan Shalawat Nariyah ini pada mulanya hanya dilaksanakan di satu tempat. Namun, seiring dengan bertambahnya jumlah jamaah shalawat nariyah dari berbagai wilayah Kroya, sampai saat ini tercatat beberapa masjid dan musala rutin berkesempatan menjadi tuan rumah.

\section{Resepsi Jamaah terhadap Tradisi Shalawat Nariyah}

Resepsi merupakan satu bentuk teori yang berkembang dalam dunia sastra dalam menganalisis teks, akan tetapi konsep tersebut pada praktiknya dapat juga dipakai untuk melakukan penelitian teks-teks nonsastra. Kata resepsi berasal dari kata "recipere" (Latin), "reception" (Inggris) yang berarti penerimaan atau penyambutan (Ratna, 2008: 165). Endraswara menyatakan bahwa resepsi berarti penerimaan atau penikmatan sebuah teks oleh pembaca (Endraswara, 2003: 118). Resepsi 
merupakan aliran yang meneliti teks dengan bertitik tolak kepada pembaca yang memberi reaksi atau tanggapan terhadap teks itu.

Jika proses resepsi dikaitkan dengan praktik living hadis, maka terdapat jarak yang jauh antara praktik yang ada saat ini dengan realitas teks hadis yang ada pada masa lalu. Karenanya sangat mungkin bila seseorang atau suatu masyarakat tidak memahami bahwa suatu praktik itu berawal atau berdasar dari hadis tertentu (Qudsy, 2016: 185). Resepsi bukan sekedar proses menerima dan merespons sesuatu, melainkan proses penciptaan makna yang dinamis di antara interaksi pembaca dengan teks. Proses resepsi merupakan pengejawantahan dari kesadaran intelektual. Kesadaran ini muncul dari perenungan, interaksi serta proses penerjemahan dan pemahaman pembaca. Apa yang telah diterima oleh pembaca, distrukturasikan kembali dan dikonkretkan dalam benak. Anggapan yang telah terkonstruksi tersebut membentuk semacam ruang penangkapan (wahrnehmungsraum) dimana materi-materi yang didapatkan tadi menjadi semacam kontur bagi dunia yang individual. Dengan kata lain, kesadaran sebagai kerangka dan tempat konkretisasi, membentuk rangkaian yang dapat menghubungkan jejak-jejak kognitif, sehingga pemahaman dan resepsi menjadi sangat memungkinkan (Jannah, 2017: 28).

Wolfgang Iser beranggapan bahwa di dalam proses penerimaan teks ada efek terbuka yang dapat dimaknai oleh pembaca. Dalam proses penerimaan teks terjadi hubungan komunikasi timbal balik antara teks dengan pembaca. Untuk mengungkap komunikasi antara teks dan pembaca perlu ada landasan teori yang mendukung. Mengingat konsep dasar kajian ini berasal dari Iser yang beranggapan bahwa proses penerimaan pembaca merupakan suatu proses fenomenologis, maka teori digunakan adalah teori tentang implied reader yang dikembangkan oleh Iser.

Menurut Iser, sebuah teks, tidak terkecuali hadis, hanya memiliki makna ketika ia dibaca oleh reader. Oleh karena itu pembacaan merupakan syarat utama dari sebuah proses interpretasi. Pusat objek pembacaan dari sebuah kajian sastra adalah interaksi antara struktur yang melekat pada teks dan penerimaan atau respons terhadap teks. Dalam setiap kajian sastra terdapat dua kutub yang saling berlawanan. Yakni "artistik" dan "estetis". Artistik bertolak dari teks author, sementara estetis bertolak dari tindakan respons reader terhadap teks. Sasaran utama kajian sastra terletak pada suatu tempat antara interaksi keduanya. Objek ini tidak dapat direduksi menjadi realitas teks maupun subjektivitas reader. Dari format pembacaan yang demikian maka akan terlihat bagaimana dinamisme interpretasi terhadap suatu teks. Respons 


\section{Achmad Fachrur Rozi}

pembaca terhadap teks akan dipengaruhi oleh perspektif subjektivitasnya, latar belakang keilmuan dan lingkungan spiritual yang mengelilinginya (Isser, 1987: ix).

Dalam hal ini, hadis tentang shalawat diimplementasikan ke dalam sebuah tradisi dari generasi ke generasi yang mengalami perkembangan secara dinamis. Tradisi shalawat nariyah di desa Kroya, awalnya muncul sebagai kegiatan rutin di sebuah pondok pesantren, kemudian dikembangkan pula di masyarakat. Tradisi Pembacaan Shalawat Nariyah ini dilaksanakan setiap malam Rabu dengan dihadiri puluhan jamaah dari masjid maupun musala di wilayah Kroya. Meskipun banyak hadis yang menganjurkan membaca shalawat di hari Jumat, pemilihan hari Rabu di sini juga bukan tanpa sebab. Menurut Muslimin, tradisi ini tidak dilaksanakan di malam Jumat maupun hari Jumat karena pada waktu tersebut jamaah memiliki agenda rutin di masing-masing tempat tinggalnya, yakni Yasinan. Sehingga dipilihlah malam Rabu sebagai waktu rutin tradisi shalawat nariyah ini. Hal ini merujuk pada gurugurunya yang memulai sesuatu di malam Rabu maupun hari Rabu.

Dalam Kitab Ta'limul Muta'allim karya Az-Zarnuji. Kitab ini merupakan kitab yang dikaji oleh hampir seluruh pesantren di Indonesia, terutama di tahun pertama memulai pendidikan di pesantren salaf. Hal ini disebabkan karena di dalam kitab tersebut mengajarkan tata krama belajar ilmu agama. Sumber utama materi kitab tersebut adalah pengalaman para ulama yang sukses menjadi ulama besar dengan kedalaman ilmu yang luar biasa, ilmunya bermanfaat bagi banyak orang, dan berhasil mendidik murid-muridnya menjadi orang yang sukses seperti diri mereka. Terkadang, praktik para ulama itu didasarkan kepada sebuah hadis. Seperti tradisi mengawali belajar pada hari Rabu.

Az-Zarnuji mengamati metode mengajar gurunya, Burhanuddin alMarghinani al-Hanafi, pengarang kitab al-Hidayah fi Fiqhil Hanafiyyah. Gurunya selalu memulai mengajar materi baru pada hari Rabu. Menurut sang guru, kebiasaan itu didasarkan kepada hadis Nabi Muhammad saw. yang mengatakan :

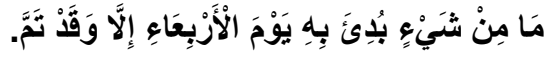

"Tiada pekerjaan yang dimulai pada hari Rabu kecuali pasti akan maksimal/sempurna." (Az-Zarnuji: 15). Pekerjaan dalam hal ini mencakup seluruh kegiatan yang baik. Di antaranya adalah kegiatan belajar dan mengajar. Para ulama menjadikan hadis ini sebagai dasar untuk mengawali pengajian mereka pada hari Rabu. 
Dasar lainnya adalah kebiasaan Imam Abu Hanifah $(150 \mathrm{H})$, pendiri mazhab Hanafi, guru yang berhasil dan pedagang sukses. Juga kebiasaan Syekh Abu Yusuf al-Hamdani. Menurut Syekh Abu Yusuf, kebiasaannya itu karena didasari pemikiran bahwa hari Rabu adalah hari diciptakannya cahaya dan hari keberuntungan bagi orang yang beriman. Demikianlah penjelasan Syekh az-Zarnuji tentang keutamaan dan anjuran memulai belajar pada hari Rabu. Dari penjelasan beliau, kita dapat menyederhanakan bahwa beliau menggunakan kebiasaan para ulama dan juga hadis Nabi Saw. sebagai dasarnya. Perlu dicatat beberapa hal sebelum memasuki uraian lebih dalam. Pertama, Syekh az-Zarnuji berbicara tentang keutamaan. Bukan berbicara tentang halal-haram atau boleh-tidaknya sebuah perbuatan. Kedua, keutamaan dapat berarti kesunnahan atau afdhaliyah. Keutamaan dengan demikian berarti anjuran.

\section{KESIMPULAN}

Tradisi Shalawat Nariyah di Desa Kroya menjadi salah satu upaya untuk mendekatkan masyarakat pada nilai-nilai Islami sekaligus mengimplementasikan sabda Nabi dalam sebuah tradisi yang nyata. Kemunculan tradisi di masjid lingkungan pesantren ini bukan hal yang tabu, karena salah satu peran masjid yakni merupakan pusat kebudayaan. Jaringan-jaringan pengajian agama di lingkungan masyarakat luas dibangun, kitab-kitab keagamaan ditulis dan disebarluaskan, dan tradisi-tradisi muncul dan berkembang hingga akhirnya mampu bertahan hingga saat ini dari generasi ke generasi. Peran pondok pesantren di sini juga terbilang vital, karena Kyai Haji Nur Hasyim sendiri termasuk santri jebolan pesantren tersebut. Tradisi ini merupakan transmisi dari keprihatinan Kyai Haji M. Minhajul Adzkiya yang merupakan ayah dari KH. Su'ada, melihat kondisi masyarakat di sekitar Kroya yang masih kekurangan sentuhan nilai-nilai Islami. Karena itu pada tahun 1951/1962, Kiai Minhajul Adzkiya bersama KH. Munawwir Alhafidz mendirikan Pondok Pesantren Miftahul Huda Kroya, sebagai media untuk berdakwah dan mengaderisasi santri, agar dapat menyiarkan agama Islam. Meski secara resmi didirikan pada 1951, tetapi cikal bakal pondok pesantren itu sudah ada sejak sebelum kemerdekaan.

Masyarakat Kroya khususnya jamaah shalawat nariyah percaya bahwa jika ia secara konsisten mengamalkan shalawat nariyah, segala hajatnya akan terkabul dengan cepat dan semua urusannya diperlancar. Kajian mengenai tradisi shalawat di Indonesia masih sangat minim. Padahal jika diterusuri praktik yang berkembang di masing-masing 
daerah bisa jadi berbeda satu sama lain. Tentu hal ini menarik untuk dikaji lebih jauh dan peluang bagi penelitian selanjutnya.

\section{DAFTAR PUSTAKA}

Ali, F. \& Effendi, B. (1986). Merosotnya Aliran dalam Partai Persatuan Pembangunan dalam Farchan Bulkin (ed.), Analisa Kekuatan Politik di Indonesia. Jakarta: LP3ES.

Al-Maliky, 'A. (T.Th). Mafahim Yajibu 'an Tushahhiha. Kairo: Dar Jawami' al-Kalim.

An-Nazi, M. H. (1993). Khazinat al-Asrar. Beirut: Dar el-Kutub alIlmiyah.

Anwar, M. K. (2015). Living Hadis. Jurnal Farabi 12, (1).

Azra, A. (1994). Jaringan Ulama. Bandung: Mizan.

Az-Zarnuji, Burhan al-Islam. Ta'lim al-Muta'allim.

Badan Pusat Statistik Kabupaten Cilacap. (2017). Kecamatan Kroya dalam Angka Tahun 2017. Cilacap: BPS.

Data Pemerintah Desa Kroya tahun 2018.

Endraswara, S. (2003). Metodologi Penelitian Sastra: Epistemologi, Model, Teori dan Aplikasi. Yogyakarta: Pustaka Widyatama.

Fikri, H. K. (2018). Agama dalam Eksistensi Pemahaman Tradisionalis Masyarakat Indonesia: Upaya Membedah Agama Perspektif Tradisional Ekstrem dan Antisipasi Konflik Bermotif Agama. SANGKéP: Jurnal Kajian Sosial Keagamaan, 1(1), 49-60.

Haedari, A. (2004). Masa Depan Pesantren dalam Tantangan Modernitas dan Tantangan Kompleksitas Global. Jakarta: IRD Press.

Hidayah, N. (2018). Kaderisasi Kepemimpinan Pesantren Terhadap Putra Kiyai Studi Kasus di Pondok Pesantren Al-Iman Bulus Purworejo. SANGKéP: Jurnal Kajian Sosial Keagamaan, 1(2), 143-165.

Horikoshi, H. (1987). Kyai dan Perubahan Sosial, terj. Umar Basalim dan Andi Muarly Sunrawa. Jakarta: P3M.

http:/ / nahdlatululama.id/blog/2018/03/03/pesantren-miftahul-hudakroya/ diakses pada tanggal 16 Mei 2018. 
https://lirboyo.net/kenapa-sholawat-nariyah/ diakses pada tanggal 16 Mei 2018.

Husni, Z. M. (2012). Shalawat Seribu Hajat: Membedah Rahasia Shalawat Nariyah. Yogyakarta: Pustaka Amaliyah.

Iskandar, A. M. (2007). Gus Dur, Islam dan Kebangkitan Indonesia. Yogyakarta: Klik R.

Ismail, F. (1998). Paradigma Kebudayaan Islam: Studi Kritis dan Refleksi Historis. Yogyakarta: Titian Ilahi Press.

Isser, W. (1987). The Act of Reading A Theory of Aesthetic Response. London: The Johns Hopkins Press Ltd.

Jannah, I. L. (2017). Resepsi Estetik Terhadap Alquran pada Lukisan Kaligrafi Syaiful Adnan. Jurnal Nun. Vol. 3, No. 1, 28.

Kuntowijoyo (1991). Paradigma Islam: Interpretasi untuk Aksi. Bandung: Mizan.

Madjid, N. (1989). "Partisipasi Politik Umat Islam Indonesia" dalam Muntaha Azhari Abdul Mun'im Saleh (ed.), Islam Indonesia Menatap Masa Depan. Jakarta: P3M.

Mas'ud, A. 1997. The Pesantren Architects and Their Socio-Religious Teaching (1950-1950), (Disertasi tidak diterbitkan), University of California Los Angeles.

Mustaqim, A. \& Syamsuddin, S. (2007). Metodologi Penelitian Living alQur'an dan Hadis. Yogyakarta: Teras.

Qomar, M. (2000). NU Liberal: Dari Tradisionalisme Ahlussunnah ke Universalisme Islam. Yogyakarta: Tiara Wacana.

Qudsy, S. Z. (2016). “Living Hadis: Genealogi, Teori dan Aplikasi” Jurnal Living Hadis, Vol. 1, No. 1.

Rafiq, A. (2005). Book Review: Rethinking the Qur'an: Membaca Qur'an di antara Teks dan Diskursus. Jurnal Studi al-Qur'an dan Hadis. Yogyakarta: IAIN Sunan Kalijaga.

Ratna, I. N. K. (2008). Teori, Metode, dan Teknik Penelitian Sastra. Yogyakarta: Pustaka Pelajar.

Shihab, M. Q. (2006). Wawasan Al-Qur'an tentang Zikir dan Doa. Jakarta: Lentera Hati.

Tim Penyusun (2008). KBBI Pusat Bahasa Edisi Keempat. Jakarta: Gramedia Pustaka. 
Achmad Fachrur Rozi

Wahid, A. (2001). Menggerakkan Tradisi, Esai-esai Pesantren. Yogyakarta: LKiS.

Wawancara dengan Kyai Muslimin, Selasa, 7 Agustus 2018 di Mushala Al-Barokah Kroya.

Wawancara dengan Kyai Waridin Selasa, 3 April 2018 di Mushala Baitut Tholibin, Jalan Sindoro Kroya.

Yunus, M. (2007). Kamus Arab Indonesia. Jakarta: PT. Mahmud Yunus. 